\title{
Pelatihan Hypnoparenting untuk Meningkatkan Motivasi Orang Tua dalam Membimbing Pembelajaran Online Anak Usia Dini pada Masa Pandemi COVID-19
}

\author{
Yuli Salis Hijriyani \\ IAIN Ponorogo \\ hijriyani@iainponorogo.ac.id
}

\begin{abstract}
Since the Covid-19 pandemic come to Indonesia, all of the education activity was doing at home. Transition learning activities from school to home is becoming heavy homework that was felt by all parents. The reason is that most parents do not understand the appropriate learning strategies for their children because what has been done so far is by using conventional methods of parenting. The best care for children is not an easy process in which parents need knowledge of parenting skills (the ability to raise children). Hypnoparenting training is one of the developments in parenting skills development because it becomes the basic foundation for parents to build the best care for their children. The training is carried out through several stages, including (1) preparation for the implementation of training in the form of an agreement on the implementation time, (2) implementation of hypnotherapy training with approximately 50 participants consisting of RA teacher parents (3) evaluation stage, the evaluation is to see the effectiveness of the implementation of hypnoparenting training. Through hypnoparenting training, parents gain knowledge of parenting skills from an early age by involving the child's subconscious to become an effective parenting model. The training activities carried out on three May 2020 had a positive impact on increasing parents' motivation in developing fun online learning activities at home during the Covid-19 pandemic.
\end{abstract}

Keywords: Hypnoparenting; Motivation; Pandemic; Covid-19

\begin{abstract}
Abstrak
Semenjak wabah Covid-19 memerangi Indonesia semua aktifitas pendidikan dilakukan dirumah, transisi kegiatan belajar mengajar dari sekolah ke rumah menjadi PR berat yang dirasakan semua orang tua. Pasalnya Sebagian besar orang tua belum memahami strategi pembelajaran yang tepat bagi anaknya, karena yang selama ini dilakukan adalah dengan cara pengasuhan metode konvensional. Pengasuhan yang terbaik bagi anak bukan suatu proses yang mudah dalam menjalankannya orang tua membutuhkan pengetahuan tentang aspek parenting skill (kemampuan mengasuh anak). Pelatihan hypnoparenting salah satu perkembangan pengetahuan di dunia parenting skill, karena hal ini menjadi pondasi dasar
\end{abstract}


bagi para orang tua guna membangun pengasuhan terbaik untuk anak. Pelatihan yang dilakukan melalui beberapa proses tahapan diantaranya adalah (1) persiapan pelaksanaan pelatihan berupa perjanjian kesepakatan waktu dilaksanakannya,(2) pelaksanaan pelatihan hypnoterapi dengan peserta kurang lebih 50 orang terdiri dari orang tua guru RA (3) tahapan evaluasi, evaluasi yang dilakukan adalah melihat keefektifan pelaksanaan pelatihan hypnoparenting. Melalui pelatihan hypnoparenting orang tua memperoleh pengetahuan keterampilan mengasuh anak sejak dini dengan melibatkan alam bawah sadar anak sehingga menjadi model pengasuhan yang efektif. Kegiatan pelatihan yang dilaksanakan tiga mei 2020 memiliki dampak positif terhadap peningkatan motivasi orang tua dalam mengembangkan kegiatan pembelajaran online dirumah secara menyenangkan pada masa pandemi Covid-19.

Keywords: Hypnoparenting; Motivasi; Pandemi; Covid-19

\section{Pendahuluan}

Di penghujung tahun 2019 seluruh dunia digemparkan dengan munculnya suatu wabah virus Covid-19, kurang lebih 114 negara sudah terjangkit virus tersebut. Wabah ini menelan korban hingga lebih 1000 orang telah terjangkit virus Covid-19, WHO membuat pernyataan bahwa kejadian ini merupakan public health emergencies international concern (PHEIC) (Sebayang, 2020). Pernyataan tersebut diartikan sebagai suatu kejadian yang membutuhkan cepat tanggap dari pemerintahan untuk meminimalisir penyebaran virus Covid-19. Covid-19 telah dinyatakan sebagai pandemi sehingga semua pemerintah di berbagai negara menerapkan karantina atau lockdow. Begitupun sama halnya pemerintah Indonesia menetapkan kebijakan pembatasan interaksi individu antar individu sebagai upaya mengatasi wabah virus Covid-19 (UNICEF, 2020). Upaya tersebut dilakukan agar virus Covid-19 tidak mudah menyebar secara luas dan upaya-upaya yang dapat memberikan kesembuhan pada pasien Covid-19. Di Indonesia kasus pertama terdeteksi di awal tahun 2020 tepatnya pada dua maret 2020 sehingga berdampak pada sektor pendidikan termasuk kegiatan belajar mengajar di pendidikan anak usia dini.

Kegiatan belajar mengajar (KBM) yang semula tatap muka dikelas semenjak awal pandemi pembelajaran dilakukan secara online. Belajar secara online harus memanfaatkan teknologi seperti televisi, smartphone, laptop, dan internet karena beberapa kegiatan pembelajaran bisa menggunakan teknis secara video call antara guru dan anak (UNICEF, 2020). Pada KBM secara online memerlukan dukungan penuh dari semua pihak baik dari kepala sekolah, guru dan orang tua (Wardhani \& Krisnani, 2020: 59).

Dukungan orang tua terhadap pembelajaran online dapat meningkatkan efektifitas kegiatan belajar anak dirumah, tentu bekerjasama dengan guru di sekolah (Rimbarizki \& Susilo, 2017: 6). Namun yang terjadi adalah orang tua 
merasa terbebani dengan adanya tugas-tugas yang setiap harinya harus dilakukan bersama anak dirumah. Sehingga berdampak pada proses pembelajaran online di rumah kurang efektif karena semangat orang tua yang menurun dengan beban tugas yang diberikan guru terhadap orang tua (Atiqoh \& Dina, 2020: 46-50). Padahal semangat orang tua dalam membimbing anak dalam pembelajaran online di masa pandemi menentukan keberhasilan dalam mencapai tujuan belajar anak. Oleh karena itu, pada pengabdian masyarakat kali ini akan mengupas tentang Pelatihan hypnoparenting sebagai upaya meningkatkan motivasi orang tua dan guru PAUD dalam kegiatan belajar mengajar (KBM) di rumah pada masa pandemi Covid-19.

\section{Metode}

Kegiatan pengabdian masyarakat ini merupakan suatu upaya untuk meningkatkan motivasi orang tua dan guru PAUD melalui hypnoparenting dalam mendukung pembelajaran online dirumah. Kegiatan ini terdiri dari perencanaan, pelaksanaan, hingga pada evaluasi kegiatan pelatihan. Perencanaan yang telah dilakukan adalah observasi lapangan untuk mengetahui sejauh mana metode pola asuh yang digunakan oleh orang tua murid di lembaga sekolah tersebut. Ditindak lanjuti dengan ditetapkannya rencana pelatihan yang akan dilakukan yakni pada tanggal tiga Mei 2020. Pada pelaksanaannya yang menjadi sasaran pelatihan ini adalah orang tua murid dan guru PAUD dan realisasi pelaksanaannya sesuai dengan rencana awal yaitu tanggal tiga Mei 2020. Setelah acara selesai dilakukanlah evaluasi dan pembagian kuesioner untuk mengetahui pengalaman yang telah didapatkan setelah pelatihan. Dalam kegiatan pengabdian ini dilakukan pada jenjang PAUD yakni di Lembaga pendidikan Yayasan Nurul Ikhlas Suryakanta Tasikmalaya pada hari sabtu, tiga Mei 2020.

Strategi pelatihan yang dilakukan pada kegiatan pengabdian masyarakat dengan dua cara yaitu: ceramah sekaligus tanya jawab tentang hypnoparenting kaitannya dengan memotivasi dirinya sendiri. Kedua adalah praktik pelatihan hypnoparenting secara langsung bersama orang tua dan guru PAUD. Hasil pengabdian masyarakat ini bahwa sebagian besar dari peserta pelatihan menyadari bahwa minimnya dukungan orang tua dan guru PAUD pada pembelajaran online anak usia dini dirumah. Pada kegiatan teknik pengumpulan datanya berupa observasi dan dokumentasi, kemudian salah satu yang lainnya adalah dengan wawancara secara langsung. Adapun tahapan analisis data yang telah berupa reduksi data, penyajian data dan penarikan kesimpulan.

Adapun tujuan dari pelaksanaan pelatihan hypnoparenting ini adalah untuk memberikan edukasi kepada orang tua dan guru PAUD tentang metode pengasuhan yang efektif baik di sekolah maupun di rumah. Keberlanjutan yang diharapkan adalah peran orang tua dan guru PAUD mendidik anak mampu memiliki tujuan searah dalam memberikan pendidikan dan pengasuhan pada anak. Oleh karena itu, materi yang disampaikan meliputi pengenalan metode hypnoparenting, bagaimana cara 
kerja hypnoparenting terhadap otak bawah alam sadar manusia dan materi terakhir adalah tips menjalankan hypnoparenting dalam kehidupan seharihari.

\section{Hasil dan Pembahasan}

\section{a. Konsep pelatihan Hypnoparenting}

Hypnoparenting memiliki arti dari dua suku kata yakni hypnosis dan parenting. Hypnosis yakni suatu seni berkomunikasi yang digunakan seseorang untuk menyampaikan pesan kepada pikiran alam bawah sadar manusia (Putra, 2012: 21). Pengertian lainnya adalah suatu cara berkomunikasi verbal maupun nonverbal secara persuasif dan segestif kepada individu sampai pada bereaksi sesuai dengan sistem nilai dasar spiritual yang dimilikinya (Noer, 2010: 17). Sedangkan parenting memiliki makna suatu pengetahuan yang mengandung pembahasan tentang cara orang tua mengasuh anak (Putra, 2012: 21). Suatu perihal tugas-tugas orang tua yang semestinya dijalankannya dan tanggung jawab terhadap perkembangan anak.

Dari pengertian diatas maka dapat diartikan bahwa hypnoparenting adalah suatu hal yang mampu menggabungkan pengetahuan cara mendidik anak dengan pengetahuan hypnosis. Sehingga dapat diartikan bahwa hypnoparenting merupakan suatu upaya atau kegiatan yang dilakukan oleh orang tua dan pendidik dengan memetakan dan membuat sistemasi semua hal yang berhubungan dengan tugas sebagai orang tua dan pendidik.

Maka dapat diartikan bahwa pelatihan hypnoparenting adalah memberikan pengetahuan sekaligus praktik kepada orang tua dengan sistematis dan sederhana tentang metode pola asuh pada alam bawah sadar orang tua. Ketika sudah masuk pesan dan kesan yang telah disampaikan, harapannya setiap orang tua dan guru PAUD mampu mengimplementasikan pola asuh secara mudah dan tanpa adanya suatu paksaan.

\section{b. Hasil}

Berdasarkan hasil dari analisis data yang dilakukan bahwa orang tua yang telah mengikuti hypnoparenting memiliki pemahaman yang meningkat tentang cara mendidik anak usia dini. Hal tersebut ada kaitannya dengan kapasitas pemahaman orang tua yang selama ini hanya mengetahui cara mendidik anak dengan cara tradisional. Cara yang dilakukannya hanya berupa punishment dan dilakukan tanpa adanya reward, sehingga mengakibatkan anak memiliki ketakutan dalam melakukan bereksplorasi suatu kegiatan.

Banyaknya keluhan dari orang tua tentang pembelajaran online pada masa pandemi ini membuat kegiatan belajar anak dirumah kurang efektif karena minimnya pengetahuan tentang cara mendidik anak. Pembelajaran online dengan cara pemberian tugas dari guru untuk anak yang dibimbing langsung oleh orang tuanya cukup menyita waktu, menguras tenaga dan 
biaya. Terlebih pada pengeluaran kuota internet karena setiap anak harus melaporkan kegiatannya dapat berupa video dan juga gambar hasil kegiatan.

Beragam kegiatan tugas dari guru tersebut, memberikan arti penting bahwa orang tua menyadari bahwa mendidik anak itu perlu pengetahuan dan keterampilan. Dua hal tersebut menjadi modal dasar sebagai upaya meningkatkan semangat anak dalam mengikuti pembelajaran online yang dilakukan dirumah. Kemampuan peran orang tua yang optimal akan menghasilkan keberhasilan pembelajaran anak dirumah dengan hasil maksimal. Oleh karena itu, sangat sekali motivasi orang tua dalam beragam cara mendidik anaknya. Maka dengan adanya pelatihan hypnoparenting ini menjawab kekurangan yang selama ini terjadi di masa pandemi Covid-19. Adapun Peningkatan pemahaman pada orang tua dalam mendidik anak memiliki dampak baik terhadap cara menghadapi anak. Dampak lainnya yang dirasakan pada masa pandemi Covid-19 ketika peran orang tua dalam mendampingi pembelajaran online dirumah. Melalui kegiatan pelatihan ini para peserta pelatihan merasakan adanya sugesti yang positif yang masuk ke dalam pikiran bawah sadarnya. Setelah dilakukan pelatihan hypnoparenting terdapat peningkatan motivasi orang tua dalam mendukung pembelajaran online sehingga membuat anak nyaman dan senang belajar di rumah.

\section{c. Pembahasan}

Wabah virus Covid-19 menjadikan situasi diberbagai sektor kehidupan berubah termasuk pada kebijakan pendidikan. Mekanisme pembelajaran yang semula tatap muka di sekolah berubah menjadi pembelajaran secara online dirumah. Sementara itu, sekolah yang senantiasa sebuah tempat berkumpul para pembelajar terkena imbas karena tidak boleh ada kerumunan dan perkumpulan guna mencegah penularan virus Covid-19.

Hal tersebut disikapi oleh kebijakan pemerintah dengan diluncurkannya pembelajaran secara online untuk melanjutkan kegiatan pembelajaran di sekolah. Berbagai platform menjadi sorotan setiap lembaga sebagai media pembelajaran online seperti aplikasi zoom meeting, google meet, grup whatsapp, google classroom dan e-learning. Beberapa platform tersebut mengharuskan setiap orang tua melek IT agar dapat menerima informasi dan melakukan aktifitas pembelajaran di rumah.

Proses kegiatan belajar dirumah yang diberikan oleh guru kepada anak membuat orang tua harus meluangkan waktu, menguras tenaga, dan biaya. Terlebih pada orang tua yang belum terbiasa melakukan aktifitas belajar bersama anak dirumah, kondisi tersebut membuat orang tua dipaksa harus membagi waktu dan menyelesaikan secara tepat guna menunjang keberhasilan setiap tugas yang diberikan guru terhadap anaknya.Serangkaian proses kegiatan belajar dan keperluan dirumah harus seimbang dilakukan, tak jarang setiap orang tua mengeluhkan kebijakan pembelajaran daring. Maka dari itu support system perlu didapatkan orang tua sebagai dukungan atas apa yang harus dikerjakannya. Pelatihan 
hypnoparenting bagian dari dukungan untuk memberikan pemahaman terkait model pengasuhan yang dapat diberikan oleh orang tua pada anak.

Respon yang baik dari para peserta pelatihan hypnoparenting sebagai upaya meningkatkan motivasi orang tua dalam membimbing pembelajaran online di masa pandemi Covid-19. Hal tersebut sesuai dengan hasil kuesioner yang telah dijawab oleh semua peserta pelatihan. Mereka berpendapat bahwa kegiatan ini sangat bermanfaat untuk mengembalikan semangat orang tua dalam mendampingi anak belajar dirumah. Menjadi orang tua memang bukan suatu hal yang sangat mudah dan setiap orang tua pasti ingin memberikan segala yang terbaik bagi anaknya. Tapi ada kalanya sebagai orang tua menemukan problematika tersendiri dalam mengurus anaknya, dengan problematika yang muncul menjadikan orang tua perlu dan butuh dukungan dari lingkungan sekitar. Sebuah pelatihan hypnoparenting sebagai wadah untuk membangkitkan semangat dan memotivasi orang tua membimbing anak pada kegiatan pembelajaran online dirumah. Sehingga kegiatan pelatihan ini menjadi alternatif solusi yang bisa diimplementasikan kepada anak sejak usia dini.

\section{Kesimpulan}

Persebaran virus Covid-19 menjadikan semua dunia berubah termasuk pada dunia pendidikan. Pendidikan mengalami transisi, mulai dari pembelajaran secara regular di sekolah menjadi pembelajaran daring di rumah. Semua hal itu menjadi sorotan bagi orang tua yang belum terbiasa dengan aktifitas belajar dengan anak. Tak jarang keluhan pun datang dari mereka karena menganggap tambahan beban kerja dirumah. Oleh karena itu, pengetahuan parenting skil sangat dibutuhkan bagi setiap orang tua. Pelatihan hypnoparenting yang dilaksanakan di RA Nurul Ikhlas Tasikmalaya menjadi solusi bagi orang tua dalam meningkatkan motivasi, dalam rangka mendampingi kegiatan pembelajaran online dirumah. Sehingga para orang tua dapat menciptakan suasana pembelajaran online yang mudah dan menyenangkan.

\section{Daftar Pustaka}

Atiqoh, L. N., \& Dina, B. (2020). Respon Orang Tua terhadap Pembelajaran Daring pada Masa Pandemi Covid-19. Thufuli: Jurnal Ilmiah Pendidikan Islam Anak Usia Dini, 2(1), 45-52. doi: 10.33474/thufuli.v2i1.6925

Noer, M. (2010). Hypnoteaching for Success Learning. Yogyakarta: Pedagogia.

Putra, I. P. P. (2012). The Miracle Conversational Hypnosis. Yogyakarta: Pohor Cahaya.

Rimbarizki, R., \& Susilo, H. (2017). Penerapan Pembelajaran Daring Kombinasi dalam Meningkatkan Motivasi Belajar Peserta Didik Paket C Vokasi di Pusat Kegiatan Belajar Masyarakat (PKBM) PIONEER Karanganyar. J+PLUS UNESA, 6(2), 1-12. 
Sebayang, R. (2020, March 12). Alert! WHO Resmi Tetapkan Corona Pandemi. Retrieved 8 January 2021, from News website: https://www.cnbcindonesia.com/news/20200312064200-4-

144245/alert-who-resmi-tetapkan-corona-pandemi

UNICEF. (2020). Covid-19 dan Anak-anak di Indonesia, Agenda Tindakan untuk Mengatasi Tantangan Sosial Ekonomi. Jakarta: United Nations Children's Fund. Retrieved from United Nations Children's Fund website: https://www.unicef.org/indonesia/reports/Covid-19-andchildren-in-indonesia

Wardhani, T. Z. Y., \& Krisnani, H. (2020). Optimalisasi Peran Pengawasan Orang Tua dalam Pelaksanaan Sekolah Online di Masa Pandemi Covid-19. Prosiding Penelitian dan Pengabdian kepada Masyarakat, 7(1), 48-59. doi: 10.24198/jppm.v7i1.28256 